\title{
A Comparative Study: Need for Affiliation and Gratitude among Young Adults Who Are/Aren't In a Relationship
}

\author{
Sneha Gulati ${ }^{1 *}$, Shifali Nehria ${ }^{1}$, Dharmesh Meena ${ }^{1}$, Mohd Mustafa ${ }^{1}$
}

\section{ABSTRACT}

Humans, as social beings, have an inherent need for affiliation. This need to form social relationships and maintain them varies in degree from individual to individual. Need for affiliation is a need for open and sociable interpersonal relationships. A common definition of gratitude is "the quality of being thankful; readiness to show appreciation for and to return kindness;". Researchers have conceptualized gratitude as an emotion that is always directed towards appreciating the helpful actions of other people (c.f. McCullough, Kilpatrick, Emmons, \& Larson, 2001).

The aim of the present investigation was to compare among young adults who are in a relationship with those who aren't on their need for affiliation and feeling of general gratitude. It was hypothesized that need for affiliation and gratitude will be more in people who are in a relationship from those who aren't and there will also be gender differences in gratitude and need for affiliation. A sample of 210 participants of the age group 18-24 were selected from which 105 were in a relationship and 105 have never been in a relationship. Need for affiliation was assessed using Liking People Scale developed by E.E. Filsinger (1981) and gratitude using the Gratitude Questionnaire-6 by Michael E. McCullough (2002). Results shall be discussed in light of role of chosen variables and were interpreted in terms of their significance.

Keywords: Affiliation, Gratitude.

Interpersonal attraction is the attraction that happens between people that lead to the formation of either friendship or romantic relationship. It is a relationship between two people characterized by a general liking but range of variation that includes respect, love, lust and affection. According to interpersonal attraction principle, social psychologist have identified several major factors that influence interpersonal attraction which is anything bring two or more people together characterized by affection respect, liking or love “ Interpersonal Attraction 2010”.

\footnotetext{
${ }^{1}$ Department Of Psychology, Panjab University, Chandigarh

*Responding Author

(c) 2016 I S Gutati, S Nehria, D Meena, M Mustafa; licensee IJIP. This is an Open Access Research distributed under the terms of the Creative Commons Attribution License (http://creativecommons.org/licenses/by/2.0), which permits unrestricted use, distribution, and reproduction in any Medium, provided the original work is properly cited.
} 


\section{A Comparative Study: Need for Affiliation and Gratitude among Young Adults Who Are/Aren't In a Relationship}

\section{Interpersonal Relationship}

Interpersonal relationship refers to a strong bond between two or more people. Attraction between individuals brings them close to each other and eventually results in a strong interpersonal relationship. According to Maslow's hierarchy of needs, humans need to feel love (sexual/nonsexual) and acceptance from social groups and society (family, peer groups). In fact, the need to belong is so naturally established that it may be strong enough to overcome physiological and safety needs relationship.

\section{Affiliation}

The concept of affiliation, (from the Latin "afiiatio") can be defined as acceptance or also friendly, accepting, open social behaviour characterized by seeking presence of others, interest in cooperation, communication and social contacts.

The need of affiliation is one of three acquired needs laid out by psychologist David Clarence McClelland in his theory on the motivations for human behaviour and defined need for affiliation as "the desire to establish and maintain many rewarding interpersonal relationships"

It can be defined as acceptance or friendly, accepting, open to social behaviour and having interest cooperation, communication and social contacts. The desire for affiliation with others has been described as a fundamental part of human nature (Wong \& Csikszentmihalyi 1991). Affiliation can be viewed as psychical needs related with the need of love friendship and cooperation. Henry Murray in his Affection Needs defined affiliation as, to be close and loyal to another person, pleasing them and winning their attention and friendship. A person having high need for affiliation is motivated build relationship with other people that many of his/her thoughts, emotions and actions are directed towards to fulfilling this motivation.

A study conducted by Craig A. Hill (1991) suggested that a person having a strong need for affiliation may be more likely to express that need, if the interaction was warm and compassionate yet, where as a person with low need for affiliation conveyed little inclination to care whether the interaction was compassionate or not.

\section{Gratitude}

'Gratitude' is derived from the Latin word 'gratia', which means 'grace', 'graciousness', or 'gratefulness'. Gratitude operates in terms of being grateful to someone, being grateful for something, being grateful to a person for something in particular or the tendency to experience gratitude as ongoing across situations (Snyder \& Lopez, 2007).

Research by UC Davis psychologist "Robert Emmons”, author of “ Thanks!: How The New Science of Gratitude Can Make You Happier”, shows that simply keeping a gratitude journal and regularly writing brief reflections on moments for which we're thankful, can significantly 


\section{A Comparative Study: Need for Affiliation and Gratitude among Young Adults Who Are/Aren't In a Relationship}

increase well-being and life satisfaction."Robert Emmons" suggests that focusing our gratitude over people for whom we are thankful rather than circumstances or materialistic items will enhance the benefits we experience.

Gratitude may also convey many benefits for couples. Perhaps the most apparent potential benefit is through its role as a positive expression of appreciation to a partner.

Past research has shown that an individual who expresses gratitude is not only providing a positive expression to a partner but is also conveying an acknowledgement, and appreciation for the partner.

\section{REVIEW OF LITERATURE}

\section{Gratitude And Relationship}

To have and to hold: Gratitude promotes relationship maintenance in intimate bonds, study done by Gordon, Amie M.; Impett, Emily A.; Kogan, Aleksandr; Oveis, Christopher; Keltner, Dacher show that people who feel more appreciated by their romantic partners report being more appreciative of their partners.

Gratitude as a Motivator and a Detector of Maintenance Behaviour, Kaska E. Kubacka, Catrin Finkenauer et al founded that feelings of gratitude toward a partner stem from the partner's relationship maintenance behaviors, partly because such behaviors create the perception of responsiveness to one's needs.

Lambert, Clark, et al (2010) found that expressing gratitude to a romantic partner or a close friend led to the expresser's increased sense of communal strength, or responsibility for the partner's well being.

Algoe, Gable and Maisel (2010) found that gratitude predicted increased relationship satisfaction for both benefactors and recipients. This study provides important findings establishing gratitude as a relevant factor among romantic couples.

\section{Affiliation Studies}

The Study 'Tend and Befriend-Bio-behavioural basis of Affiliation under stresses, conducted by Shelley E. Taylor, found that positive affiliative contact significantly reduces not only psychological, but also biological stress responses.

Mc Adams and Constantian (1983), person high in affiliation compensate for the dissatisfaction they typically expect in relationships by seeking out new ones. 


\section{A Comparative Study: Need for Affiliation and Gratitude among Young Adults Who Are/Aren't In a Relationship}

\section{Affiliation And Gender}

Women have consistently scored higher than men on enjoyment of social interaction, agreeableness, and have tended to be more sociable.

It has also been found that women tend to form dyad affiliations, where they bond with the "other" one-on-one and go on to do this "bonding" with many individuals. Men, on the other hand, bond in larger groups. However, it has also been found that men have larger social networks. Women have more intimate affiliations while men are more oriented towards exercising their power. (Rose, 2009)

\section{Hypothesis:-}

It was hypothesized that need for affiliation and gratitude will be more in people who are in a relationship from those who aren't and there will also be gender differences in gratitude and need for affiliation.

\section{METHODOLOGY}

\section{Participant:-}

A total of 210 participants (both male and female) were taken for the study where $50 \%$ were in a relationship and 50\% were single. The age group of participants was 18 to 24 years.

\section{Research Design}

T-test, correlation and One Way ANOVA is used.

\section{Variables}

There are two types of variable used in the present study i.e. dependent variable and independent variable.

\section{INDEPENDENT VARIABLE}

1. Relationship Status

2. Gender differences.

\section{DEPENDENT VARIABLE}

1. Gratitude

2. Need for affiliation

\section{Research Tools}

1. The gratitude questionnaire-six item form (GQ-6)

2. Liking people scale.

\section{Description of tools:}

1. The gratitude questionnaire-six item form (GQ-6) developed by Michael E. McCullough, Ph.D., Robert A Emmons, Ph.D., Jo-Ann Tsang Ph.D. It consists of 6 items and items 3 and 6 are scored reverse.

2. Liking people scale developed by Dr. Erik E Filsinger, Mandara Vishwanath. It consists of 15 items and items 4, 6, 8, 9, 10, and 15 are scored reverse. 


\section{Procedure:}

Participants were contacted directly as well as google forms were created to survey. The participants were instructed to mark the responses honestly and were told that their forms will be kept confidential. The data was analysed using statistical tests.

\section{RESULTS}

Table 1: F values of gratitude and affiliation among committed and single young adults. Independent Samples Test

\begin{tabular}{|l|l|l|l|l|}
\hline \multicolumn{2}{|c|}{} & \multicolumn{2}{|l|}{ t-test for Equality of Means } \\
\cline { 3 - 5 } \multicolumn{2}{|c|}{} & $\mathbf{t}$ & Df & Sig. (2-tailed) \\
\hline \multirow{2}{*}{ G total } & $\begin{array}{l}\text { Equal variances } \\
\text { assumed }\end{array}$ & .303 & 208 & .762 \\
\cline { 2 - 5 } & $\begin{array}{l}\text { Equal variances not } \\
\text { assumed }\end{array}$ & .303 & 207.024 & .762 \\
\hline A total & $\begin{array}{l}\text { Equal variances } \\
\text { assumed }\end{array}$ & -1.261 & 208 & .209 \\
\cline { 2 - 5 } & $\begin{array}{l}\text { Equal variances not } \\
\text { assumed }\end{array}$ & -1.259 & 205.433 & .209 \\
\hline
\end{tabular}

Table 1. Displays the $\mathrm{f}$ values of gratitude and affiliation among committed and single young adults with significance values (.762 and .209) as they are more than 0.05 so there is no significant difference among committed and singles on need for affiliation and gratitude.

Table 2: F values of gratitude and affiliation in different age groups ANOVA

\begin{tabular}{|l|l|l|l|l|}
\hline \multicolumn{2}{|c|}{} & Mean Square & F & Sig. \\
\hline \multirow{4}{*}{ G total } & Between Groups & 5.176 & .459 & .632 \\
\cline { 2 - 5 } & Within Groups & 11.268 & & \\
\cline { 2 - 5 } & Total & & & \\
\hline A total & Between Groups & 562.771 & 5.877 & .003 \\
\cline { 2 - 5 } & Within Groups & 95.760 & & \\
\cline { 2 - 5 } & Total & & & \\
& & & & \\
\hline
\end{tabular}

Table 2. Displays the $\mathrm{f}$ values and significant values of the different age groups among the young adults showing a significant difference between groups in need for affiliation at .003. 
Table 3: Significance values of affiliation in the 3 age groups

Tukey HSD

\begin{tabular}{|l|l|l|l|l|}
\hline \multicolumn{2}{|l}{ Values of affiliation in different age groups } & Mean Difference (I-J) & Sig. \\
\hline \multirow{4}{*}{ Atotal } & $18-20$ & $21-22$ & $-5.19900^{*}$ & .004 \\
\cline { 3 - 5 } & $23-24$ & -1.56920 & .730 \\
\cline { 2 - 5 } & $21-22$ & $18-20$ & $5.19900^{*}$ & .004 \\
\cline { 2 - 5 } & $23-24$ & 3.62979 & .118 \\
\cline { 2 - 5 } & $23-24$ & $18-20$ & 1.56920 & .730 \\
\cline { 2 - 5 } & $21-22$ & -3.62979 & .118 \\
\hline
\end{tabular}

Table 3. shows three different age groups (18-20, 21-22, 22-24) and their level of significance in the need for affiliation. In the age group of 18-20 and 21-22, affiliation is significant at .004 but it is not significant for the age group 22-24.

Table 4: Gender Differences in Need for affiliation and Gratitude

\begin{tabular}{|l|l|l|l|l|}
\hline \multicolumn{2}{|l}{} & \multicolumn{2}{l}{ t-test for Equality of Means } & Sig. (2-tailed) \\
\cline { 3 - 5 } & \multicolumn{1}{|l|}{ t } & Df & .346 \\
\hline \multirow{2}{*}{ G total } & $\begin{array}{l}\text { Equal variances } \\
\text { assumed }\end{array}$ & -.945 & 208 & .362 \\
\cline { 2 - 5 } & $\begin{array}{l}\text { Equal variances not } \\
\text { assumed }\end{array}$ & -.914 & 164.552 & .031 \\
\hline A total & $\begin{array}{l}\text { Equal variances } \\
\text { assumed }\end{array}$ & -2.171 & 208 & .030 \\
\cline { 2 - 5 } & $\begin{array}{l}\text { Equal variances not } \\
\text { assumed }\end{array}$ & -2.189 & 199.434 & \\
\hline
\end{tabular}

Table 4. shows that there is a significant difference .030 in females in their need for affiliation.

Table 5: Correlation Between Gratitude And Need For Affiliation.

\section{Correlations}

\begin{tabular}{|c|c|c|c|}
\hline & & G total & A total \\
\hline \multirow{3}{*}{ G total } & Pearson Correlation & 1 & $-.213^{* *}$ \\
\hline & \begin{tabular}{|l|} 
Sig. (2-tailed) \\
\end{tabular} & & .002 \\
\hline & $\mathrm{N}$ & 210 & 210 \\
\hline \multirow{3}{*}{ A total } & Pearson Correlation & $-.213^{* *}$ & 1 \\
\hline & Sig. (2-tailed) & .002 & \\
\hline & \begin{tabular}{|l|}
$\mathrm{N}$ \\
\end{tabular} & 210 & 210 \\
\hline
\end{tabular}




\section{A Comparative Study: Need for Affiliation and Gratitude among Young Adults Who Are/Aren't In a Relationship}

Table 5 shows a negative correlation at .002, calculated using Pearson correlation. Negative correlation indicates that with increase in gratitude, need for affiliation will decrease and with increase in need for affiliation gratitude will decrease and vice versa.

\section{DISCUSSION}

The aim of the present investigation was to study if there were any significant differences between people who are in a relationship from those who aren't on their need for affiliation and general life gratitude. For this, a sample of 210 youth between age group 18-24 were taken and tested. Four results came out of this investigation.

We made our first hypothesis stating that the need for affiliation and gratitude will be more in people who are in a relationship. With the help of t test we analyzed the data and results showed that there is no significant difference among committed and single. There can be various possible reasons for such results; one of them could be the increase in the use of social networking sites from where need for affiliation may be fulfilled by connecting with many people. Also having a loving and caring environment with family and friends can lead to increase in their general life gratitude and fulfillment of one's need for affiliation rather than by being in a relationship. In 2002, a study was conducted on $10 \%$ students of Ohio State University, "Ed Diener” and "Martin Seligman", conducted a study on personal happiness. They found that the most salient characteristics shared by the students who were very happy and showed the fewest signs of depression were "their strong ties to friends and family and commitment to spending time with them. In one study people were asked about their mood on random occasions.

We know that our thinking keeps on changing as we grow and gain experience; we divided the population into 3 age-groups; 18-20, 21-22, 23-24 to study diversity among age-differences. We then analyzed the gratitude and need for affiliation among the three age groups separately and founded that, in the age group 18-20 and 21-22, the mean difference is significant at the 0.05 level but not for the age group 23-24. However, there were no differences on their general life gratitude. This meant that need for affiliation is more in the age group of 18-22 and low for the people of age group 23-24. The age group between 23-24 are grown ups, where the focus is more on making carriers, settling in life or even planning to make a family whereas the age group between 18-22 are developing their base in educational institutions and to grow in lives and also due to neurological changes.

We also assessed the gender differences between male and female on their need for affiliation and gratitude and found that there was a significant difference (.030) in females in their need for affiliation thus our hypothesis was accepted. This result is supported by many studies. Stewart and Chester (1982) in their research showed that women scored higher in need for affiliation than men. Studies by Oetzel (1966) show that girls and women exceed boys and men on diverse measures of need for affiliation and interest in and positive feeling for others. Garai and 


\section{A Comparative Study: Need for Affiliation and Gratitude among Young Adults Who Are/Aren't In a Relationship}

Scheinfeld's (1968) evidence suggested that males have a great interest in objects and a stronger need for achievement, females a greater interest in people and a stronger need for affiliation.

We also found the correlation between need for affiliation and gratitude using Karl Pearson correlation and found negative correlation at .002 that indicates that with increase in gratitude, need for affiliation will decrease and with increase in need for affiliation gratitude will decrease and vice versa.

\section{CONCLUSION}

The investigation was completed with four findings. Firstly, that there was no significant difference between committed and singles on their need for affiliation and gratitude. The sample was divided into three age-groups and it was found that need for affiliation was significant for the age group 18-20 and 21-22 compared to age-group 23-24. While analyzing the gender differences it was found that females have a higher need for affiliation. Lastly there was a negative correlation between gratitude and need for affiliation.

\section{LIMITATIONS OF THE STUDY}

1. The sample size used for the study is rather small.

2. Only a segment of the young adult population has been studied (Early Young Adulthood18 to 24 years of age.)

3. The study is limited only to urban, metropolitan population.

4. The sampling method used could have been more segregated.

\section{FUTURE IMPLICATIONS}

Need for affiliation is manifested in different ways in the two genders. For instance, women prefer dyads and men prefer groups. This understanding can be applied to community and hierarchical relations in work places. A higher need for affiliation can affect one's leadership style. For example, a person with high need for affiliation tends to work in a collaborative style rather than authoritative. Studies such as this may be easily carried out using samples from rural areas and observe if there is any disparity.

\section{REFERENCES}

Abraham H Maslow. (1943). A Theory of Human Motivation. Psychological Review, 381.

Algoe, S. B., Gable, S. L., \& Maisel, N.C. (2010). It's the little things: Everyday gratitude as a booster shot for relationships. Personal Relationships, 17, 217-233.

Algoe, S. B., Haidt, J., \& Gable, S. L. (2008). Beyond reciprocity; Gratitude and relationships in everyday life. Emotion, 8, 425-429

Filsinger, D. E. (1981). A measure of Interpersonal Orientation-The Liking People Scale. Journal of Personality Assessment, 295-300 


\section{APPENDIX:}

\section{Liking People Scale}

Using the scale below as a guide, write a number beside each statement to indicate how much you agree with it.

5- Strongly Agree

4-Moderately Agree

3-Neutral

2-Moderately Disagree

1-Strongly Disagree:

1 Sometimes when people are talking to me, I find myself wishing that they would leave.

2 My need for people is quite low.

3 One of the things wrong with people today is that they are too dependent upon other people.

4 My happiest experiences involve other people.

5 People are not important for my personal happiness.

6 Personal character is developed in the stream of life.

7 I could be happy living away from people.

8 It is important to me to be able to get along with other people.

9 No matter what I am doing, I would rather do it in the company of other people.

10 There is no question about it - I like people.

11 Personal character is developed in solitude.

12 In general, I don ${ }^{e} t$ like people.

13 Except for my close friends, I don "et like people.

14 A person only has a limited amount of time and people tend to cut into it.

15 People are the most important thing in my life.

\section{The Gratitude Questionnaire-Six Item Form (GQ-6)}

Using the scale below as a guide, write a number beside each statement to indicate how much you agree with it.

$1=$ strongly disagree 2 = disagree $3=$ slightly disagree $4=$ neutral $5=$ slightly agree $6=$ agree 7

= strongly agree

1. I have so much in life to be thankful for.

2. If I had to list everything that I felt grateful for, it would be a very long list.

3. When I look at the world, I don't see much to be grateful for.*

4. I am grateful to a wide variety of people.

5. As I get older I find myself more able to appreciate the people, events, and situations that have been part of my life history.

6. Long amounts of time can go by before I feel grateful to something or someone.

How to cite this article: S Gutati, S Nehria, D Meena, M Mustafa (2016) A Comparative Study: Need for Affiliation and Gratitude among Young Adults Who Are/Aren't In a Relationship, International Journal of Indian Psychology, Volume 3, Issue 3, No. 5, DIP: 18.01.089/20160303 